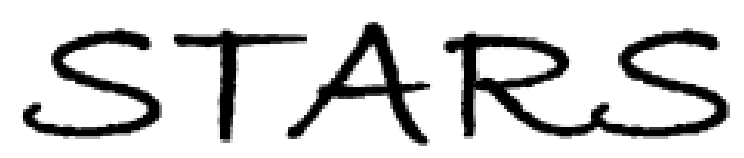

University of Central Florida

STARS

Faculty Scholarship and Creative Works

$9-1-2020$

\title{
The "If-Then" Rules Matter More? The Roles of Regulatory Focus and Leader-member Exchange
}

You-De Dai

Wen-Long Zhuang

Annie Ko

Fevzi Okumus

University of Central Florida, Fevzi.Okumus@ucf.edu

Part of the Hospitality Administration and Management Commons, and the Tourism and Travel Commons

Find similar works at: https://stars.library.ucf.edu/ucfscholar

University of Central Florida Libraries http://library.ucf.edu

This Paper is brought to you for free and open access by STARS. It has been accepted for inclusion in Faculty Scholarship and Creative Works by an authorized administrator of STARS. For more information, please contact STARS@ucf.edu.

\section{Original Citation}

Dai, Y.-D., Zhuang, W.-L., Ko, A., \& Okumus, F. (2020). The "if-then" rules matter more? The roles of regulatory focus and leader-member exchange. International Journal of Hospitality Management, 90, N.PAG. https://doi.org/10.1016/j.ijhm.2020.102602

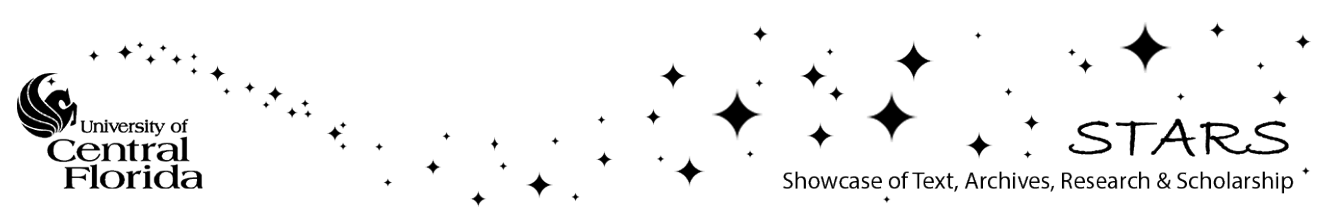




\title{
The 'if-then' rules matter more? The roles of regulatory focus and leader-member exchange
}

\author{
You-De Dai, Wen-Long Zhuang, Annie Ko, Fevzi Okumus
}

\begin{abstract}
This study aimed to explore the impact of regulatory focus on employees' effort behavior and social loafing in the context of international tourist hotels. The moderating effect of leadermember exchange on this causal relationship was also examined. Data were analyzed using a regression model of 708 valid responses obtained from frontline employees working in fivestar international hotels. The results reveal that regulatory focus is positively related to effort behavior and partially supports social loafing. Leader-member exchange moderates the relationship between promotion focus and effort behavior as well as between prevention focus and effort behavior. These findings provide managerial implications for hotel managers in regard to predicting positive work behavior and minimizing negative behavior in the workplace.
\end{abstract}

Keywords: Effort behavior, Hotel frontline employees, Leader-member exchange, Regulatory focus, Social loafing

\section{Highlights}

- In hospitality organizations enhancing positive work behavior and minimizing negative ones should always be on the top agenda of managers.

- Study results confirm that frontline employees will exhibit stronger positive effort behavior when their promotion focus and prevention focus are stronger.

- Managers should pay closer attention to developing and communicating the linkage (ifthen rules) between a given task and an expected gain.

- Study results indicate that prevention-focused employees are significantly and negatively correlated to social loafing.

- Employees' orientation to regulatory focus is not a static personality trait but a choice based on their cognitive understanding of the causation.

\section{Acknowledgements}

The authors would like to thank the Editor-in-Chief, Dr. Manuel Rivera, and two reviewers who provided valuable comments on the manuscript. The research was supported by the grant from Taiwan Ministry of Science and Technology (to You-De Dai) (Reference No. MOST 105-2410-H-260-026-SSS). 


\section{Introduction}

In the hotel industry, frontline employees face intensive work stress as a result of long working hours, organizational politics, emotional dissonance, and work-family conflicts (Dai, Chen, \& Zhuang, 2016; Dai, Dai, Chen, \& Wu, 2013; Karatepe, Beirami, Bouzari, \& Safavi, 2014). Due to the service nature of their work roles in maintaining frequent and close interaction with customers and the increasing demand of handling timely requests or complaints (Karatepe \& Baddar, 2006), these challenges may decrease service employees' job performance (Karatepe \& Kilic, 2007) or effective enforcement of operating procedures in service delivery (Karatepe \& Sokmen, 2006). Raub (2008) suggests that employees' interaction with customers, their service attitude, and their behavior in service delivery play key roles in customer satisfaction (Fisher, McPhail, \& Menghetti, 2010). Therefore, the level of effort employees put into service behavior is a crucial indicator of job performance (Brockner, Grover, Reed, \& Dewitt, 1992; Dai et al., 2016) and a key component the achievement of successful service (Ha \& Jang, 2009).

The work team is a primary social structure in any contemporary organization (Robbins, 2006). Nevertheless, it is not difficult to find team members who are uncooperative and unsociable (Breton, 1971); who are invisible in groups (Festinger, Pepitone, \& Newcomb, 1952); who avoid responsibility but benefit from the work accomplished by others (Dai, Hou, Wang, Zhuang, \& Liu, 2018; Dommeyer, 2007); who slack off in the context of work groups (Stark, Shaw, \& Duffy, 2007); who leave group production behind (Liden, Wayne, Jaworski, \& Bennett, 2004); and who decrease group effectiveness (Duffy \& Shaw, 2000) and group performance (Murphy, Wayne, Liden, \& Erdogan, 2003), thus having an influence on group cohesiveness (Karau \& Williams, 1997). Employees in the hospitality industry have been found to exhibit reduced effort in a work group by avoiding responsibility, shirking duties, sabotaging team leaders and/or teammates, and other deviant behaviors (Dai et al., 2016, 2018; Harris \& Ogbonna, 2002). Dai et al. (2018) and Latané, Williams, and Harkins (1979a) termed the phenomenon of an individual's getting by with less effort when working in a group as "social loafing." Social loafing is primarily associated with factors such as loss of individual coordination and motivation (Steiner, 1972) and lack of recognition of personal contribution in a group (Williams, Harkins, \& Latané, 1981). Moreover, research shows that $4 \%$ of employees exhibit dishonest behavior (Murphy, 1987) and 96\% exhibit withdrawn behavior (Slora, 1991). Anywhere from $69 \%$ to $80 \%$ of those behaviors will result in negative consequences (Boye \& Jones, 1997). In sum, employees' avoidance of responsibility and shirking one's own duties are very common phenomena in a workplace context (Dai et al., 2018; Harris \& Ogbonna, 2002).

In order to enhance the successful operation of a hotel that relies heavily on team functioning and group goals, managers must consider what psychological variables could possibly influence individuals' feelings and actions, and by that influence increase the likelihood of exhibiting high-effort (positive) behavior without engaging in the negative behavior of social loafing (Dai et al., 2016, 2018). Higgins's $(1996,1997)$ regulatory focus theory, based on the motivation and hedonic principles, introduces individuals' orientation of focus in achieving their desired end-state (or goal) namely: promotion focus or prevention focus. Gorman et al. (2012) suggested that employees who are oriented toward promotion focus have a greater effect on positive job behaviors and satisfaction than prevention focus-oriented employees. Jung and Yoon (2015) found that hotel employees' turnover intention decreases when they are motivated by 
different strategies corresponding to their regulatory focus. These two foci assume that an individual will adopt either an eager or vigilant strategy at work to achieve their goals. Eager strategy ensures that a positive result is available and avoids the lack of a positive result. On the other hand, a vigilant strategy is to make sure that there are no negative results and/or prevent them from happening (Higgins et al., 2001). In sum, hotel employees who possess a promotion-focused attitude will be self-driven and eager to accomplish their work tasks for potential gains, while prevention-focused employees will complete their task assignments driven by a mindset of responsibility or obligation, or for the reason of avoiding negative consequences of not accomplishing said task. Since hotel managers strive to enhance employees' work effort and inhibit incidence of social loafing, employees' tendency toward promotion focus or prevention focus appears to be somewhat influential, as it may help explain the psychological mechanism of an employee in the decision-making process while predicting behavioral outcomes. Earlier studies established the relationship of regulatory foci on turnover intention (Jung \& Yoon, 2015), job crafting (Hetland, Hetland, Bakker, \& Demerouti, 2018), and job satisfaction and performance (van Beek, Toon, Schaufeli, \& Brenninkmeijer, 2012). Still, few studies have discussed the regulatory foci of hotel employees, despite the fact that such attitudes and behaviors are commonly observed among hospitality workers (Chang \& Teng, 2017; Jung \& Yoon, 2015; Zhao \& Namasivayam, 2012). Researchers have asserted that employees' regulatory foci and effort behavior within an organization are scarce (Gorman et al., 2012; Markovits, Ullrich, van Dick, \& Davis, 2008; Jung \& Yoon, 2015). Therefore, this study first examined the research question "Can the regulatory foci of hotel employees influence their effort behavior and social loafing?"

Previous studies indicated that the dyadic relationship, or leader-member exchange (LMX), between employees and supervisors plays a crucial role in developing the attitudes and behaviors of important followers (Dulebohn, Bommer, Liden, Brouer, \& Ferris, 2012; Ilies, Nahrgang, \& Morgeson, 2007). Past research has identified the phenomenon of collectivism and high power distance in Chinese culture (Li \& Sun, 2015). Hence, Chinese employees may show reverence for, and strive to maintain a good relationship with, their superiors. This study assumes that Chinese employees in the hotel sector will be influenced by their team leader (supervisor) and perform accordingly during service delivery. Will LMX moderate the relationship between hotel employees' orientation of promotion focus and prevention focus in relation to their work behaviors? This moderating relationship remains unexplored and requires further examination to assist managers in deriving strategic initiatives to induce employees' positive effort behavior and reduce negative social loafing. The results will shed light on employees' work attitude and subsequent service behavior, thereby enhancing the richness of tourism and hospitality literature based on the work motivation principle.

\section{Literature Review}

\subsection{Regulatory focus and effort behavior}

Higgins's (1996, 1997) regulatory focus theory (RFT) emphasized individuals' selfregulation decision-making process in pursuit of their desired end-state. Regulatory foci comprise a multi-dimensional construct of two dimensions: namely, promotion focus and prevention focus (Higgins, 1996, 1997, 1998). The strategic tendency of promotion-focused people is to "approach" advancement, growth, aspirations, and accomplishments. As Higgins (1998) pointed out, promotion-focused people are more sensitive to the presence or absence of positive outcomes, or 
pursue gain to avoid non-gain situations. Contrarily, prevention-focused people strive for maintenance and safety, adhering to their obligations and pursuing "ought to do" responsibilities to assure stability (Higgins, 1997). They are sensitive about the presence or absence of negative results, or attend to non-loss while avoiding loss situations. They consider "avoidance" as the appropriate strategic direction (Das \& Kumar, 2011).

Previous studies have pointed out the importance of the contribution of frontline employees to the organization (Danaher \& Mattsson, 1994; Reynolds \& Beatty, 1999). These employees, though, cannot substitute customers' voices, as their effort behavior leads to the outcomes of customer satisfaction and retention when accurately translating customer value in service delivery (Chen \& Quester, 2007). Therefore, the effort of employees at work is undeniably a key success factor in any organization. For instance, the hard work of employees is closely related to high performance and enterprise competitiveness (Kuczmarski \& Kuczmarski, 1995). Sujan, Weitz, and Kumar (1994) pointed out that these efforts can be indicated by a focus on working long hours to achieve objectives and constant attempts to adjust plans and strategies when encountering problems. Mohr and Bitner (1995) suggested that the efforts of service personnel can be observed when customers interact with them. Rangarajan, Jones, and Chin (2005) showed that efforts represent the force, energy, or activity required to perform and accomplish specified work tasks. High effort behavior necessitates an individual's physical (e.g., devotion of time and physical effort) and cognitive demands (e.g., mental effort of acquiring knowledge and understanding of organizational vision to accurately translate customer value to quality service). Previous studies found that organizational vision (Testa, 1999) and leader-member exchange (Dai et al., 2016) are the possible antecedents of effort behavior. In the context of this study, efforts performed by frontline employees are defined as effort behavior insofar as they represent an individual's attempt to provide quality services and to satisfy customers (Dai et al., 2016; Testa, 1999).

However, is every hotel employee willing to work hard to deliver quality service and meet customer needs? According to the regulatory focus theory (Higgins, 1996, 1997), promotionfocused employees will do their best to complete their work tasks. In achieving good customer service, they will expect positive gains (outcomes), such as compliments from supervisors or an extra year-end bonus for their outstanding performance. They will strive to heighten their efforts to accomplish the objectives set for them and to avoid a non-gain situation. On the other hand, prevention-focused employees will also try their best to achieve the same goal to maintain job security and to avoid such negative consequences as customer complaints. They are sensitive to loss situations, such as lack of a year-end bonus or job loss, if frequent customer complaints are received. Since providing service is the "ought to do" responsibility of any frontline employee in a hotel, they will make further efforts to reduce customer dissatisfaction. Therefore, this study contends that:

H1a. The stronger hotel employees' promotion focus is, the more their effort behavior will be.

H1b. The stronger hotel employees' prevention focus is, the more their effort behavior will be.

\subsection{Regulatory focus and social loafing}

George (1992) and Karau and Williams (1993) defined social loafing as the tendency of individuals to make less effort when performing work in groups (working collectively) as opposed to working alone (working individually). The concept was first used to explain anticipated 
problems in a social context when an individual underperforms in a work group (Latané, Williams, \& Harkins, 1979b). Social loafing is detrimental to the productivity and performance of groups or organizations at large (Meyer, Schermuly, \& Kauffeld, 2016). Some of the common outcomes include lower productivity and reduced group commitment (Mulvey and Klein, 1998), which in turn may result in poor-quality service during customer interaction (Luo, Qu, \& Marnburg, 2013), thereby harming an organization's positive climate and success in the long run (Luo et al., 2013). Dai et al. (2018) pointed out that social loafing has a moderating effect on the relationship between team-member exchange and perceived accountability. The study suggested that low levels of social loafing among team members can ultimately increase an individual's extra-role, higher-effort behaviors. Therefore, social loafing is useful for explaining the contribution of individuals to groups that are often difficult to examine (Williams, Harkins, \& Latané, 1981).

Basing our research on RFT to further our understanding of ameliorating negative social loafing behavior in work teams, we contend that promotion-focused employees who aspire to perform well individually for positive outcomes will accomplish the same in a work team. They strive to ensure the overall success of their collective goal (e.g., providing excellent customer service). They also contribute to the team in the same way and exhibit less social loafing behavior. Prevention-focused employees who strive to accomplish their responsibilities through avoidance strategies will also exhibit less social loafing, because cooperating with their team members, working collectively to achieve group goals, is their obligation. To avoid a loss situation, they will exhibit the same amount of effort and avoid social loafing as much as they would when working individually. Therefore, we posit the following hypotheses:

H2a. The stronger hotel employees' promotion focus is, the less their social loafing will be.

$\mathrm{H} 2 \mathrm{~b}$. The stronger hotel employees' prevention focus is, the less their social loafing will be.

\subsection{The moderating role of leader-member exchange}

Leader-member exchange (LMX) is derived from social exchange theory, which explains the interaction between leaders and followers as the foundation for understanding the quality of an exchange relationship between leaders and followers (Blau, 1964). Followers' perception of LMX reflects their voluntary actions, and leaders show reciprocal feedback (e.g., Bernerth, Armenakis, Feild, Giles, \& Walker, 2007). These important perceptions explain the vertical dyad linkage between leaders and followers, and its subsequent impact of their attitudinal and performancerelated outcomes (Dansereau et al., 1975; Dulebohn et al., 2012). In a workplace context, leadermember exchange is defined as "the quality of the relationship between a subordinate and a supervisor" (Dai et al., 2016, p. 370; Dansereau, 1995). High-quality exchanges (in-group) is represented by a high degree of mutual trust and respect while low-quality exchanges (out-group) is characterized by low trust and respect (Dansereau et al., 1975). Graen and Cashman (1975) suggests that different parties in an organization contribute to the attainment of organizational goals. Each subordinate plays an important role in developing these exchanges. In a study of 315 American and 363 Chinese hotel employees, Kim, Choi, Knutson, and Borchgrevink (2017) suggests that leader-member exchange on the employees' voice and team-member exchange tends to be more critical in the Chinese context than those of the United States due to the manifestation of a deep respect for leaders. This study purports to investigate the moderating effects of LMX in the context of Chinese hotel employees' work behavior. 
According to RFT (Higgins, 1996, 1997), the effort behavior performed by hotel employees may be affected by promotion focus and prevention focus. According to previous studies, antecedents of effort behavior include leader-member exchange (Dai et al., 2016), role ambiguity, and role conflict (Rangarajan et al., 2005). From an interactionist perspective, hotel employees' effort behavior is the result of regulatory foci interacting with LMX. When the quality of the relationship between a supervisor and an employee is high, role ambiguity and conflict are minimized. The trust and commitment established from the supportive in-group environment will have a reinforcing effect on employees' effort behavior. Promotion-focused employees can perform even higher as they are sensitive to pursuing gain; the relationships with their supervisors will assist them in achieving their desire for advancement, growth, and accomplishments in the workplace. Therefore, we contend that LMX will moderate the relationship between promotion focus and effort behavior. Prevention-focused employees adhere to work obligations and pursue "ought to do" responsibilities. To avoid loss (e.g., underperformance, job termination) that would be detrimental to the maintenance of safety at work (e.g., job security), hotel employees in a collectivist culture tend to seek even more support from their supervisor to accomplish their daily work tasks. Therefore, we propose the following hypotheses:

H3. LMX will moderate the relationship between promotion focus and effort behavior.

H4. LMX will moderate the relationship between prevention focus and effort behavior.

Previous studies have investigated the determinants of social loafing behavior. The results of these studies suggested that decreased group cohesion (Liden et al., 2004) leads to more social loafing behavior while turnover intention mediates the relationship between co-worker support and social loafing (Akgunduz \& Eryilmaz, 2018). In the hotel context, the regulatory foci of promotion and prevention may reduce the social loafing of frontline employees. Promotionfocused employees are likely to contribute more effort in the work team as an LMX relationship, thus leading to less social loafing. Prevention-focused employees who strive for maintenance and job security tend to exercise self-reliant strategies by spending more time and effort to finish their tasks when perceiving low LMX, thus decreasing the likelihood of social loafing behavior. From the interactionist perspective, hotel employees' social loafing is the result of regulatory foci interacting with LMX. Therefore, we propose that:

H5. LMX moderates the relationship between promotion focus and social loafing.

H6. LMX moderates the relationship between prevention focus and social loafing.

\subsection{Research framework}

Figure 1 shows the conceptual framework of this study, exploring the relationship between employees' regulatory foci, LMX, effort behavior, and social loafing. 
Figure 1 Conceptual framework.

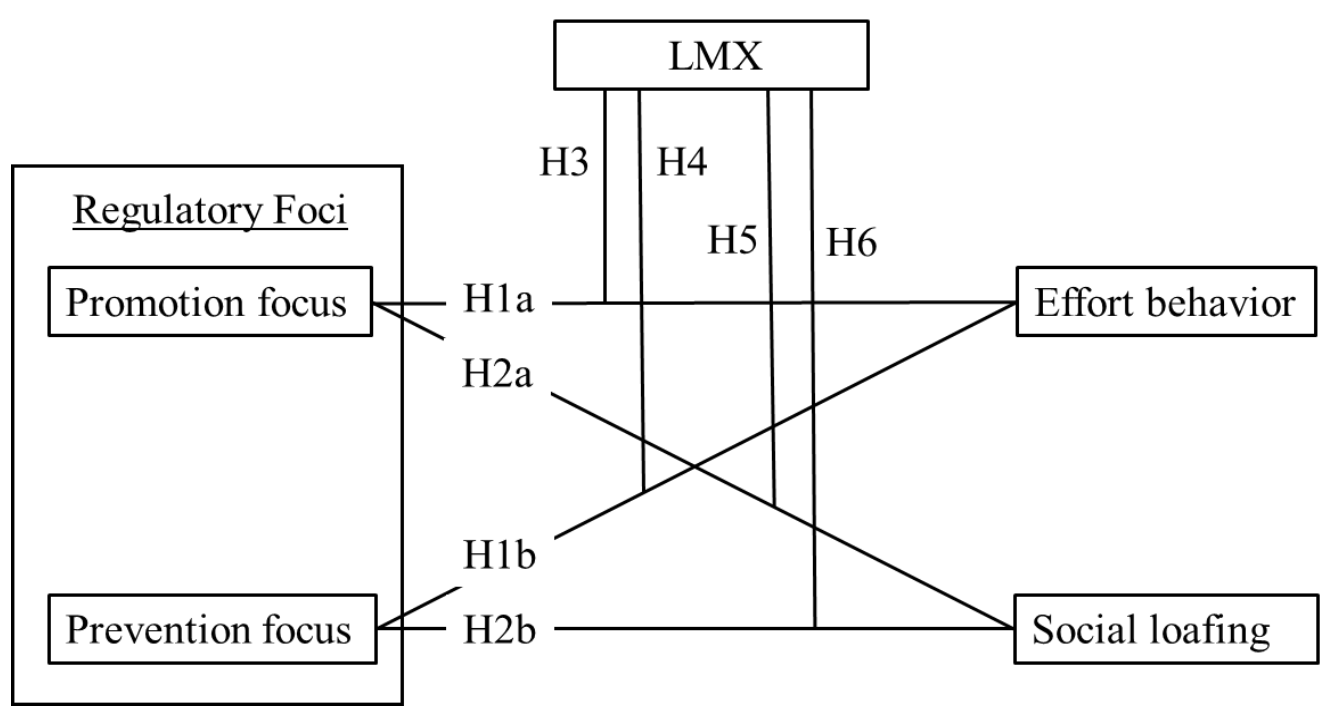

\section{Methodology}

\subsection{Sampling and data collection}

This study investigates Chinese frontline employees working in international tourist hotels. Convenience and judgmental sampling methods were adopted. Through email invitation, ten fivestar hotels indicated their willingness to participate in the study. These hotels are located in the cities of Taipei, Taichung, Kaohsiung, Xiamen, and Quanzhou along the Taiwan Strait in the South China Sea. Travelers visit these cities both for business and leisure purposes with high expectations regarding customer service. Therefore, hotel employees and managers are expected to strive for service excellence, which makes five-star hotels more suitable in this study. Human resource managers of the participating hotels were contacted for distribution of the questionnaires to their employees. A total of 150 self-administered questionnaires were delivered to ten five-star hotels in 2017. Respondents were advised to seal their completed questionnaires in the self-addressed envelope provided and return it to the researchers by post directly. This approach, suggested by Podsakoff, MacKenzie, and Podsakoff (2012), assures anonymity of the questionnaire and increases the likelihood of employees to provide honest response. In view of the study population being Chinese employees, the questionnaire was back-translated into Chinese. A pre-test of the questionnaire was conducted with sample employees to ensure its readability and face validity before the actual data collection. The questionnaire contained three sections. The first section consisted of 19 statements designed to examine respondents' orientation toward promotion focus and prevention focus as well as the perception of leader-member exchange. The second section was comprised of another 19 statements to understand their perception of effort behavior and social loafing. The last section requested demographic information regarding gender, age group, position, and tenure. A total of 1,500 questionnaires were distributed, and 708 usable responses were collected, representing a valid response rate of $47.2 \%$. Multiple regression was employed to test 
the hypothesis of this study, as it is one of the most frequently used causal modeling data analysis techniques in hospitality research (Yoo, Lee, \& Bai, 2011).

\subsection{Measurement of constructs}

To measure the constructs in this study, psychometrically sound measurement scales were adopted from previous studies. All variables were measured on a five-point Likert scale, ranging from 1 (strongly disagree) to 5 (strongly agree).

\subsubsection{Regulatory foci}

Regulatory foci were measured by a 12-item scale adopted from Wallace and Chen (2006), and which was supported by previous employees' studies of Hung, Huan, Lee, Lin, and Zhuang (2018) and Lee, Hung, Chien, Zhuang, and Hsu (2017). There are six items of promotion focus and six items of prevention focus. The Cronbach's alpha was found to be 0.88 and 0.86 respectively. Examples of items include "I always accomplish a lot of work" (promotion focus) and "I often follow the rules and regulations" (prevention focus).

\subsubsection{Effort behavior}

Effort behavior was measured by a 15-item scale developed by Sujan et al. (1994). It yielded a high Cronbach's alpha of 0.98 in a recent employees' study of work-family conflict (Dai et al., 2016). A sample item in the scale of effort behavior is "I work many hours a week."

\subsubsection{Social loafing}

Four items from Price, Harrison, and Gavin (2006) and Dai et al. (2018) were used to measure social loafing. The Cronbach's alpha was 0.87 and the items were "I often set aside my work tasks"; "I often leave my work to other colleagues"; "I often shirk my work and responsibilities"; and "When colleagues need help, I always claim that I have other things to do."

\subsubsection{Leader-member exchange}

A seven-item scale was used to measure leader-member exchange based on previous studies of Scandura and Graen (1984) and Dai et al. (2016), in which the items were modified to meet the requirements of this study. The Cronbach's alpha of LMX was 0.86 at time 1 and 0.84 at time 2 .

\subsubsection{Control variables}

This study assumed that hotel employees' age, gender, position, and tenure may influence their effort behavior and social loafing and were therefore incorporated as the control variables. 


\section{Results}

\subsection{Descriptive statistics}

The demographic profile of the respondents is Chinese frontline employees working at ten different international tourist hotels located in Taipei, Taichung, Kaohsiung, Xiamen, and Quanzhou. Among the 708 valid responses, the gender distribution was approximately equal between males and females, accounting for $51.1 \%$ and $48.9 \%$, respectively. Half of the respondents $(53.2 \%)$ were aged between 19 and 24 years of age, $28.4 \%$ were between 25 and 34, and $15 \%$ were between 35 and 54 . In terms of their position, $61.2 \%$ were general staff, $25.8 \%$ were team leaders or supervisors, while $5.8 \%$ were assistant managers or managers. Nearly half of the sample $(48.3 \%)$ had worked in their corresponding hotels for less than one year, while $31.4 \%$ had worked for one to two years, $11.6 \%$ for three to four years, and $8.7 \%$ for 5 years or more.

\subsection{Reliability and validity analysis}

The criterion for assessing the scale reliability was the use of the reliability coefficient indicated by a Cronbach's alpha of $>0.7$. The item-total correlation $>0.45$ (Dai, Zhuang, \& Huan, 2019) was referenced for item deletion. No item was deleted from the scales. The Cronbach's alpha of each construct exceeded 0.7 , indicating a good reliability of the scales. Prior to testing the relationship between these variables, confirmatory factor analysis (CFA) was used to test the measurement model and to confirm the validity of the research framework (Anderson \& Gerbing, 1988). A CFA sequence was performed using AMOS 23 to examine the validity of the variables based on chi-square statistics and fit indices of RMSEA and CFI (Anderson \& Gerbing, 1988). The results fit index of the hypothesized 5-factor model (promotion focus, prevention focus, LMX, effort behavior, and social loafing) yielded $\chi^{2}=3231.67$; degree of freedom $=655 ; \chi^{2} / \mathrm{df}=4.93$; RMSEA = .08; and CFI = .91. All fit indices were within the limits recommended by Bagozzi and Yi $(1988)\left(\chi^{2} / \mathrm{df}<5\right.$; RMSEA $\leqq 0.08$; CFI $\left.>0.80\right)$. The CFA results also indicated the distinctiveness of the five variables for subsequent analyses.

As shown in Table 1, the average variance extracted (AVE) of the variables was loaded between 0.62 and 0.87 . The results indicate that AVEs exceeded the .50 cut-off value (Fornell \& Larcker, 1981), meaning that the convergent validity was acceptable. Table 2 shows the correlation coefficients of paired variables, which were lower than the square root of the AVE for each construct except that promotion focus and prevention focus were .02 below the corresponding dimensions deemed acceptable. Most of the constructs demonstrated an acceptable level of discriminant validity (Fornell \& Larcker, 1981). 
Table 1

Confirmatory Factor Analysis

\begin{tabular}{lcc}
\hline Items & SFL & t-value \\
\hline Promotion focus & & \\
I can always do a lot of work & 0.77 & - \\
Anyway, I have to finish my work & 0.83 & 23.90 \\
can do a lot of work in a short time & 0.76 & 21.23 \\
Work tasks can make me better at work & 0.82 & 23.32 \\
I often wonder if my work is done & 0.76 & 21.33 \\
I always think about how much work I can accomplish & 0.78 & 21.95
\end{tabular}

\section{Prevention focus}

$\begin{array}{llll}0.64 & 0.66 & 0.46 & 0.91\end{array}$

I often follow the rules to work

I often complete work tasks correctly

$0.73 \quad-$

I always do my job duty

$0.79 \quad 21.01$

When working, I often think of my duties

$0.84 \quad 22.36$

I often finish my job

$0.84 \quad 22.54$

I often notice work details

$0.81 \quad 21.54$

$0.79 \quad 21.08$

\section{LMX}

$\begin{array}{llll}0.76 & 0.50 & 0.40 & 0.96\end{array}$

I know where I stand with my manager

$0.85 \quad-$

My manager has enough confidence in me that he/she would defend and justify my decisions if I was not present to do so

$0.86 \quad 30.20$

My working relationship with my manager is effective

My manager understands my problems and needs

$0.88 \quad 31.50$

$0.89 \quad 31.73$

When I really need it, I can count on my manager to "bail me out" even at his other own expense

My manager recognizes my potential

$0.86 \quad 30.09$

$0.88 \quad 31.08$

Regardless of how much power my manager has built into his

$0.87 \quad 30.90$ or her position, my manager would be personally inclined to use his/her power to help me solve problems in my work

\section{Effort behavior}

$\begin{array}{llll}0.69 & 0.58 & 0.44 & 0.97\end{array}$

I work long hours to achieve my sales objectives

I work persistently at selling a customer until he/she decides to buy the product/service

I work many hours a week

$0.84-$

$0.86 \quad 29.99$

$0.86 \quad 29.92$

When selling a challenging customer, I don't give up easily

$0.87 \quad 30.21$

I set up a weekly schedule for what I need to do

$0.87 \quad 30.51$

I think about strategies I will resort to if I encounter problems in a sales interaction

$0.80 \quad 26.38$ 


\begin{tabular}{llll}
\hline I maintain good records about my accounts & 0.84 & 28.73 \\
It is a waste of time to plan & 0.82 & 27.63 \\
I don't spend too much time on planning when I get to my & 0.78 & 25.70 \\
work & 0.85 & 29.43 \\
I am careful to work on the tasks with first priority & 0.83 & 28.36 \\
I virtually adopt the same approach with most customers & 0.83 & 28.17 \\
$\begin{array}{l}\text { It's not difficult for me to adjust my sales presentation to the } \\
\text { needs of situation }\end{array}$ & 0.82 & 27.32 \\
$\begin{array}{l}\text { I am confident that I can modify my planned presentation if } \\
\text { required }\end{array}$ & 0.80 & 26.52 \\
$\begin{array}{l}\text { I can easily change to another sales approach when I find that } \\
\text { the current one does not work }\end{array}$ & 0.75 & 23.91 \\
I adopt a set sales approach & & & \\
& & & \\
Social loafing & 0.91 & - & 0.87 \\
I often set aside my work tasks & 0.95 & 45.18 \\
$\begin{array}{l}\text { I often leave my work to other colleagues } \\
\text { I often shirk my work and responsibilities }\end{array}$ & 0.94 & 44.44 \\
$\begin{array}{l}\text { When colleagues need help, I always claim that I have other } \\
\text { things to do }\end{array}$ & 0.92 & 40.84
\end{tabular}

Table 2

Correlations for Variables.

\begin{tabular}{|c|c|c|c|c|c|c|c|}
\hline Variables & $\mathrm{M}$ & SD & 1 & 2 & 3 & 4 & 5 \\
\hline 1. Promotion focus & 3.74 & 0.67 & $\begin{array}{c}(0.79) \\
1\end{array}$ & & & & \\
\hline 2. Prevention focus & 3.86 & 0.68 & $.81^{* *}$ & $\begin{array}{c}(0.80) \\
1\end{array}$ & & & \\
\hline 3. LMX & 3.79 & 0.81 & $.66^{* *}$ & $.69 * *$ & $\begin{array}{c}(0.87) \\
1\end{array}$ & & \\
\hline 4. Effort behavior & 3.84 & 0.74 & $.74 * *$ & $.76^{* *}$ & $.71 * *$ & $\begin{array}{c}(0.83) \\
1\end{array}$ & \\
\hline 5. Social loafing & 2.35 & 1.20 & $-.28 * *$ & $-.36 * *$ & $-.41 * *$ & $-.37 * *$ & $\begin{array}{c}(0.93) \\
1\end{array}$ \\
\hline
\end{tabular}

\subsection{Hypothesis testing}

With regard to the regression analysis used to test the hypothesis in this study, all variables in the model were examined by variation inflation factors (VIF) for multicollinearity. The results of all VIF values of the variables were lower than 5, which is below the threshold of 10 (Hair, Anderson, Tatham, \& Black, 1998), signifying that these variables were appropriate to be used in the regression model. 
Hypotheses $1 \mathrm{a}$ and $1 \mathrm{~b}$ relate to the influence of regulatory foci on effort behavior. Table 3 presents the results of the multiple regression analysis with promotion focus and prevention focus as the independent variables and effort behavior as the dependent variable, while the control variables include gender, age, position, and tenure. According to Table 3, promotion focus and prevention focus have positive and significant influences on effort behavior $(\beta=0.370, p<.001)$ $(\beta=0.448, p<.001)$. Therefore, Hypotheses $1 \mathrm{a}$ and $1 \mathrm{~b}$ are supported.

\section{Table 3}

Multiple regression analysis of regulatory foci for effort behavior.

$\begin{array}{cc}\begin{array}{r}\text { Dependent } \\ \text { variable }\end{array} & \\ \text { Independent } \\ \text { variables }\end{array}$

Note: $* * \mathrm{p}<0.01, * * * \mathrm{p}<0.001, \mathrm{n}=708$

Hypotheses $2 \mathrm{a}$ and $2 \mathrm{~b}$ relate to the influence of regulatory foci on social loafing. Table 4 presents multiple regression analysis results with promotion focus and prevention focus as the independent variables, social loafing as the dependent variable, and gender, age, position and tenure as control variables. According to the results shown in Table 4, promotion focus has no significant effect on social loafing $(\beta=0.044, p>.05)$, whereas prevention focus has negative and significant effects on social loafing $(\beta=-0.376, p<.001)$. Therefore, Hypothesis $2 \mathrm{a}$ is rejected, whereas $2 b$ is supported.

\section{Table 4.}

Multiple regression analysis of regulatory foci for social loafing.

\begin{tabular}{cc}
$\begin{array}{c}\text { Dependent } \\
\text { variable }\end{array}$ & Social loafing \\
\hline $\begin{array}{c}\text { Independent } \\
\text { variables }\end{array}$ & -0.004 \\
Age & 0.055 \\
Position & $-0.142 * * *$ \\
Tenure & -0.058
\end{tabular}


Promotion focus

Prevention focus

$$
\mathrm{R}^{2}
$$

$\operatorname{Adj}-R^{2}$

$\mathrm{F}$
0.044

$-0.376^{* * *}$

0.159

0.152

$22.050 * * *$

Note: $* * \mathrm{p}<0.01, * * * \mathrm{p}<0.001, \mathrm{n}=708$.

Hypothesis 3 examines whether LMX moderates the relationship between promotion focus and effort behavior. Table 5 presents the results of multiple regression analysis with promotion focus as the independent variable, effort behavior as the dependent variable, and LMX as moderating variable, while gender, age, position and tenure serve as control variables. The results show that the interaction between promotion focus and LMX significantly predicted effort behavior $(\beta=-0.076, p<0.01)$. In order to further our understanding of the moderating directions of high LMX and low LMX, the interaction effect was plotted, using the Excel software program, by entering the unstandardized regression coefficients (including intercept/constant) of promotion focus and LMX. For hotel employees with low LMX, as shown in Figure 2, promotion focus can effectively enhance their effort behavior more than those with high LMX. As such, Hypothesis 3 is supported.

\section{Table 5}

Regression results for moderating role of LMX in the relationship between promotion focus and effort behavior.

\begin{tabular}{c|c}
$\begin{array}{r}\text { Dependent } \\
\text { variable } \\
\text { Independent } \\
\text { variables }\end{array}$ & Effort behavior \\
Gender & -0.005 \\
Age & 0.010 \\
Position & 0.019 \\
Tenure & 0.006 \\
Promotion focus & $0.453 * * *$ \\
LMX & $0.379 * * *$ \\
Promotion focus * LMX & $-0.076^{* *}$ \\
$\mathrm{R}^{2}$ & 0.640 \\
Adj-R & 0.636 \\
$\mathrm{~F}$ & $177.578^{2} * *$ \\
\hline
\end{tabular}

Note: $* * \mathrm{p}<0.01, * * * \mathrm{p}<0.001, \mathrm{n}=708$. 


\section{Figure 2}

Moderating effect of LMX on the relationship between promotion focus and effort behavior.

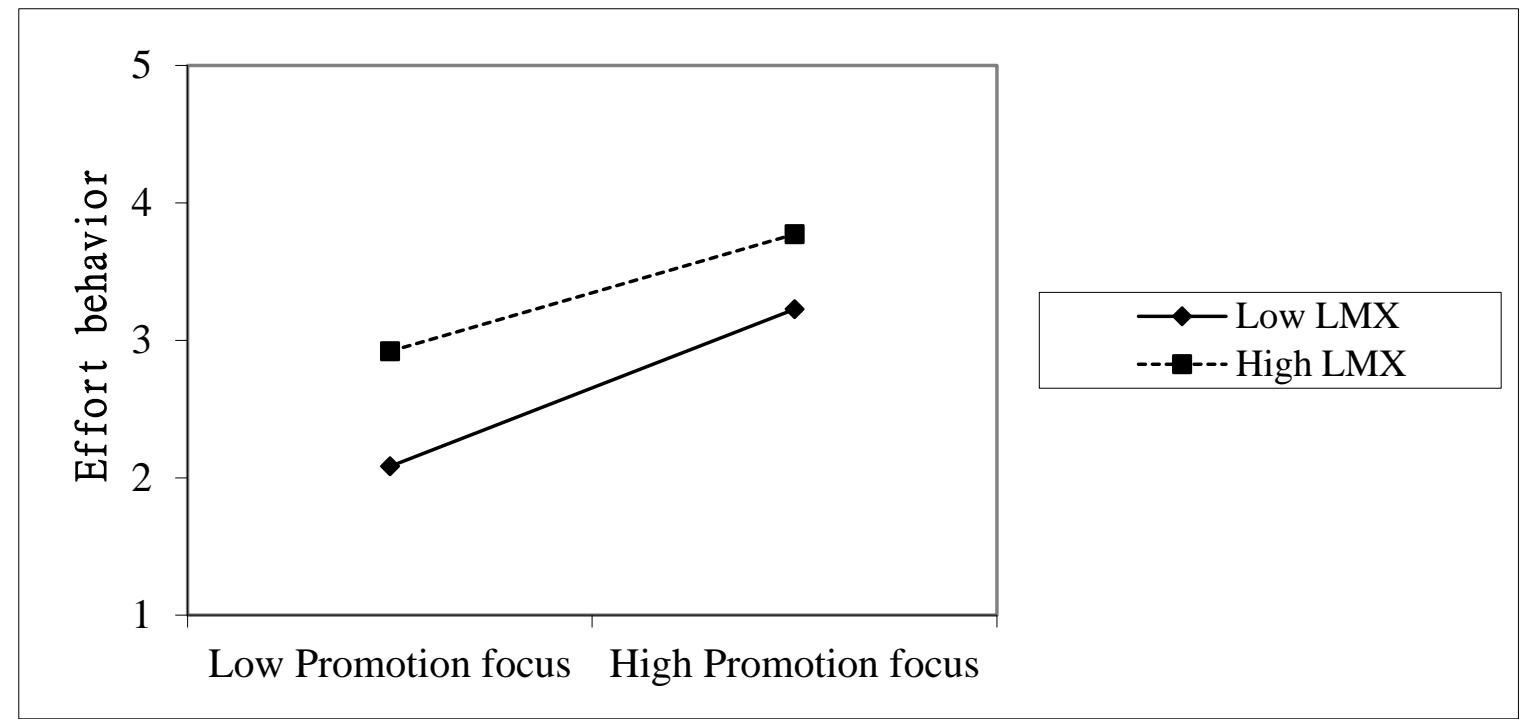

Similarly, Hypothesis 4 relates to whether LMX moderates the relationship between prevention focus and effort behavior. Table 6 presents the results of multiple regression analysis with prevention focus as the independent variable, effort behavior as the dependent variable, and LMX as moderating variable, while gender, age, position, and tenure serve as control variables. The results show that the hypothesis is supported as the interaction between prevention focus and LMX significantly predicted effort behavior $(\beta=-0.117, p<0.001)$. In order to further our understanding of the moderating directions of high LMX and low LMX, the interaction effect was plotted, using Excel, by entering the unstandardized regression coefficients (including intercept/constant) of prevention focus and LMX. As shown in Figure 3, for hotel employees with low LMX, prevention focus can effectively enhance their effort behavior more than those with high LMX. 


\section{Table 6}

Regression results for moderating role of LMX in the relationship between prevention focus and effort behavior.

\begin{tabular}{cc}
$\begin{array}{r}\text { Independent } \\
\text { variables }\end{array}$ & $\begin{array}{r}\text { Dependent } \\
\text { variable }\end{array}$ \\
Gender & Effort behavior \\
Age & \\
Position & 0.017 \\
Tenure & 0.014 \\
Prevention focus & -0.021 \\
LMX & $0.467 * * *$ \\
Prevention focus * LMX & $0.352^{* * *}$ \\
$\mathrm{R}^{2}$ & $-0.117^{* * *}$ \\
Adj-R & 0.653 \\
$\mathrm{~F}$ & 0.650 \\
\hline
\end{tabular}

Note: $* * \mathrm{p}<0.01, * * * \mathrm{p}<0.001, \mathrm{n}=708$.

\section{Figure 3}

Moderating effect of LMX on the relationship between prevention focus and effort behavior.

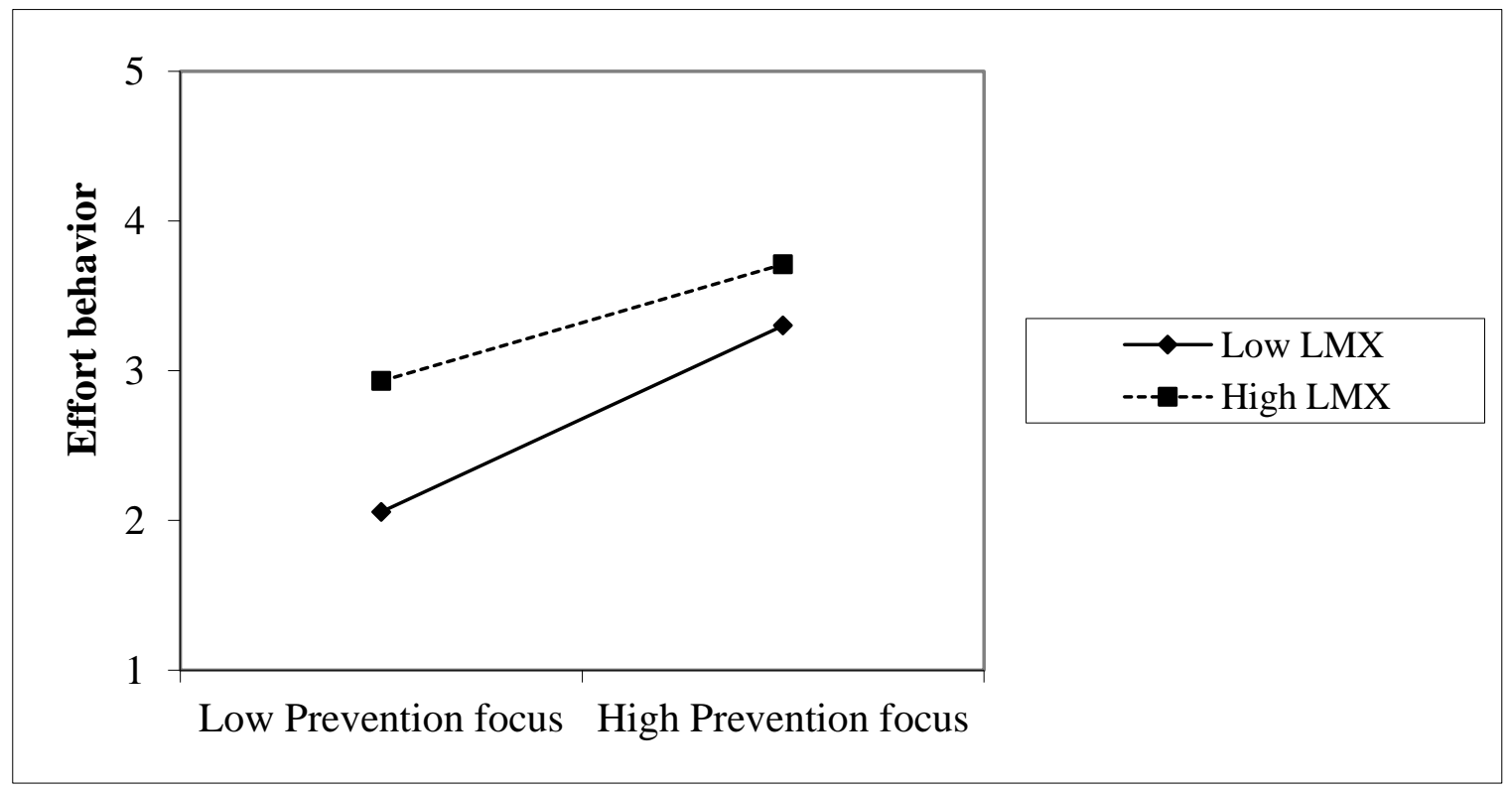

Hypotheses 5 and 6 relate to whether LMX moderates the relationship between promotion focus and social loafing, and between prevention focus and social loafing, respectively. Table 7 and Table 8 present multiple regression analysis results with promotion focus and prevention focus as the independent variable respectively, social loafing as the dependent variable, and LMX 
as moderating variable, while gender, age, position, and tenure serve as control variables. Both hypotheses were not supported as the interaction between promotion focus and LMX (Table 7) and prevention focus and LMX (Table 8$)$ failed to predict social loafing $(\beta=0.005, p>0.05)$.

\section{Table 7}

Regression results for moderating role of LMX in the relationship between promotion focus and social loafing.

$\begin{array}{cc}\begin{array}{c}\text { Independent } \\ \text { variables }\end{array} & \begin{array}{r}\text { Dependent } \\ \text { variable }\end{array} \\ \text { Gender } & 0.010 \\ \text { Age } \\ \text { Position } \\ \text { Tenure } \\ \text { Promotion focus } & 0.042 \\ \text { LMX } & -0.111^{* *} \\ \text { Promotion focus * LMX } & -0.068 \\ \mathrm{R}^{2} & 0.000 \\ \text { Adj-R } & -0.368 * * * \\ \mathrm{~F} & 0.050 \\ & 0.190 \\ \end{array}$

Note: $* * \mathrm{p}<0.01, * * * \mathrm{p}<0.001, \mathrm{n}=708$.

\section{Table 8}

Regression results for moderating role of LMX in the relationship between prevention focus and social loafing.

\begin{tabular}{cc}
$\begin{array}{r}\text { Dependent } \\
\text { variable }\end{array}$ & Social loafing \\
Independent & \\
variables & 0.006 \\
Age & 0.053 \\
Position & $-0.108^{* *}$ \\
Tenure & -0.068 \\
Prevention focus & $-0.150^{* *}$ \\
LMX & $-0.282^{* * *}$ \\
Prevention focus * LMX & 0.005 \\
$\mathrm{R}^{2}$ & 0.199 \\
Adj-R & 0.191 \\
$\mathrm{~F}$ & $24.920 * * *$ \\
\hline
\end{tabular}

Note: $* * \mathrm{p}<0.01, * * * \mathrm{p}<0.001, \mathrm{n}=708$.

\subsection{Discussion}




\subsubsection{Regulatory foci, effort behavior, and leader-member exchange}

The major finding of this study is the support of Hypothesis 1, which is consistent with previous findings that RFT can be used to explain the psychological mechanism behind employees' making of choices toward their desired end-states (or goals). The results confirmed that frontline employees will exhibit stronger positive effort behavior when their promotion focus and prevention focus are stronger. Specifically, in Hypothesis 1a, it is not difficult to see in a hotel that promotion-focused employees always think positively when they are assigned job tasks. From the perspective of motivation theory, RFT helps to explain that the work behavior displayed by promotion-focused employees is not a result of their personality but a process of self-regulation. One will consider personal feelings and thoughts then take subsequent actions by assessing the pleasure they gain from the presence of positive outcomes or the pain they perceive in the absence of positive outcomes. For example, these employees may perceive a promotion advancement opportunity in the future (presence of gain) for continuous outstanding performance. Alternatively, they may receive no compliments from customers or supervisors, indicating no hope (absence of gain) for promotion in the future. Concerned as they are about advancement, growth, and accomplishment, they constantly self-regulate in pursuit of achieving the ideal goal set by the organization. It is worth noting that this assertion is based on the employee's perception of gain non-gain. If he/she has no knowledge of what positive outcomes will be, this will impede his/her decision-making process. According to Higgins (1997), it is important to consider the "if-then" rules and communicate the gain and non-gain (in this case, with regard to promotion) information by explaining explicitly which actions would produce specific consequences. This important finding encourages managers to increase the effort behavior of promotion-focused employees by providing them a clear linkage between efforts made and subsequent outcomes.

Second, this study postulated a moderating role of LMX between promotion focus and effort behavior (H3), confirming this causal relationship with a positive effect of LMX or supervisory role in enhancing employees' devoted efforts. This finding is corroborated by Higgins (1997) in that momentary situations, such as feedback given by a supervisor to a subordinate, could enable a temporary inducement of promotion focus. This result further corresponds to the interactionist perspective that hotel employees' effort behavior is the result of regulatory foci interacting with LMX.

Another interesting finding with regard to moderating effect is that employees with low LMX can effectively enhance their effort behavior more than those with high LMX. This can be explained by the RFT that promotion-focused employees are self-regulated and are motivated to perform well and achieve the desired goal. In this circumstance, the leader-exchange relationship can significantly affect the effect of effort behavior but does not necessarily need to be high. Previous LMX studies noted challenges of leaders to develop high-quality relationships; in view of the time and resource constraints, they can usually focus on a small group of subordinates only (van Breukelen, Schyns, \& Blanc, 2006). This result provides another important implication for managers about the magnitude of relationships toward inducing promotion-focused employees. Supervisors should therefore maintain decent support systems for their subordinates but can allocate more time to increasing employees' knowledge of gain by setting clear key performance indicators (KPIs) for them to achieve, clarifying expectations, and communicating the ideal goals, developing inducements (e.g., reward programs) that tie closely with their accomplishment while 
following through with these promises. This will reinforce promotion-focused employees to continue to enhance their effort behavior.

The results also confirmed the causal relationship between prevention focus and effort behavior (H1b). As compared to promotion-focused employees, if their goal is to achieve high customer satisfaction, they may not only perform according to the standard operating procedures, but also make extra efforts, thinking "outside the box" to exceed customer needs. Preventionfocused employees may approach the same task in different ways. They follow the standard procedures and rather spend time and effort to minimize customer dissatisfaction as a means of fulfilling responsibilities and obligations in service delivery. When there are complaints due to service failure or discrepancies in service procedures, they will try their best in the service recovery process. As they are sensitive to negative outcomes and have a strong sense of duty and need for security, their strategic means of self-regulation is an inclination to avoid a mismatch with desired end-states. As such, prevention-focused employees will input effort behavior as well. Similar to the discussion above on prevention focus, the moderating effect of LMX on such behavior (H4) is also significant. Employees with low LMX can effectively enhance their effort behavior more than those with high LMX. Hence, the role of supervisor in LMX is not to develop high-quality working relationships but rather pay more attention to communicating the loss situation (e.g., penalty or punishment) if the minimum standard is not fulfilled.

\subsubsection{Regulatory foci, social loafing, and leader-member exchange}

The above discussion explains that regulatory foci can increase the likelihood of exhibiting behavior that is positive and of high effort. With regard to inhibiting employees' social loafing, which was also one of the study objectives, regulatory foci partially supported this hypothesis $(\mathrm{H} 2 \mathrm{a}$ and H2b). No moderating effect of LMX (H5 and H6) was found, suggesting that the relationship between promotion or prevention focus and social loafing will not be influenced by LMX. Social loafing finds employees putting less effort into working in groups than when working alone. The result indicates that prevention-focused employees are significantly and negatively correlated to social loafing ( $\mathrm{H} 2 \mathrm{~b}$ ). These employees understand clearly that they are part of a work team in a hotel's operational department. They perceive their role in a work team as part of their obligation and a way to fulfil their responsibility - i.e., the standard or minimum requirement when working in a team. Therefore, they self-regulate to contribute to the team as much as they contribute on their own. Conversely, the relationship between promotion-focused employees and social loafing (H2a) is insignificant. One possible reason could be an unclear gain or a non-gain situation communicated by the organization or work team. These employees may rather focus on displaying their personal achievements for the positive consequences (e.g., direct praise by customers). This may be supported by the respondents' demographic information in this study in that half of the respondents were young workers between the age of 19 and 24 years old. As members of Generation Z, they desire instant gratification (Stuckey, 2016). This interesting finding urges managers to reconsider what positive outcomes would appeal to promotion-focused employees toward reducing social loafing, thus maximizing team resources for better results. 


\section{Conclusion and Implications}

\subsection{Theoretical implications}

This study fills a gap in the hospitality literature by applying social exchange theory to develop its research framework. Echoing a call by scholars (Chang \& Teng, 2017; Jung \& Yoon, 2015) for more research on employee regulatory foci, the findings of this study should contribute to work-related outcomes in the hospitality literature. Specifically, the study furthers our understanding of the role played by motivation theory and the reciprocal relationship between organizations and employees' regulatory foci in an international hotel setting. Building on Higgins's (1997, 1998) regulatory focus theory (RFT), individuals choose to avoid pain but approach pleasure hinged on hedonic principles. RFT is more often used by marketing research to understand consumers' decision-making processes. The study by Daryanto, de Ruyter, Wetzels and Patterson (2010) provides implications for companies to create an attractive value proposition by aligning rewards with customers' needs, thereby enhancing effective customer loyalty. In employees' regulatory focus research, the psychological mechanism of how employees adopt pleasure or pain strategies at work is still unclear. According to Higgins (1997), the expected pleasure and pain of any given task can be communicated by presenting the "if-then" rules clearly. This study revealed that regulatory foci are also useful for examining the self-regulatory psychological mechanism of employees when approaching their desired goal. As in the value proposition of a reward program for customers, promotion-focused employees attend to rewards (gain) or non-gain situations. If they opt for a positive approach toward working hard, inputting high effort behavior that goes beyond delivering the standard service, then their reward will be customer compliments, extra bonuses, and promotion, whereas the "if-then" rules for reference when using the prevention (avoidance) approach are linked to the penalty (loss) or non-loss situation. Therefore, employees' orientation to regulatory foci is not a static personality trait but a choice based on their cognitive understanding of the causation and exchange relationship with the organization in question. To our knowledge, this is one of the few studies to pursue the research objective of asserting the influences of regulatory foci on work outcomes of effort behavior and social loafing in the hotel context, based on social exchange theory.

The second contribution of this study is affirmation of the moderating effect of LMX between regulatory foci and effort behavior. The interesting findings of low leader-member exchange (LMX) as a sufficient determinant for enhancing such causal relationship gives new insights with regard to the study of Chinese group dynamics. As the majority of LMX studies are searching for ways to develop high-quality interpersonal exchange relationships between subordinates and their respective leaders for organizational effectiveness and performance, the current study provides implications to solve the challenges of managers who are constantly investing time to keep high LMX for every employee of a team.

\subsection{Implications for managerial practice}

The empirical results of this study suggest the importance of regulatory focus as a motivation variable and LMX as an important moderator to induce positive work behavior and minimize negative behavior. This provides valuable implications for hotels to tackle human resources challenges regarding performance and reward management, talent development, and 
recruitment and selection of frontline employees. With regard to performance and reward management, the study explains that employees choose their work strategies (promotion focus or prevention focus) based on their sensitivity to gain and non-gain situations or loss and non-loss situations, respectively. If hotels are determined to increase promotion-focused employees or turn existing prevention-focused employees into promotion-focused ones, they should not underestimate the power of perceived cognitive linkages. First, managers should pay more attention to developing and communicating the linkage ("if-then" rules) between a given task or an ultimate goal (e.g., key performance indicators (KPIs) or customer satisfaction index) and an expected gain or reward (e.g., extra year-end bonus). If employees are well-informed by their HR system that the concept of procedural justice and outcome is embedded in the design and evaluation process to ensure fairness, they will be self-driven to accomplish the goal and achieve the perceived gain. Second, managers or supervisors' role in the leader-member exchange should be not only to provide decent support but also mentor team members to excel higher by explicitly laying out the consequences of non-gain situations (e.g., no extra year-end bonus). If they are aware of the existence of an unfavorable situation, they will continue working as high achievers via promotion-focused strategies and extra-role behaviors. On the other hand, unclear gain or nongain situations or inconsistencies of reward mechanism communicated by the organization or supervisor will create confusion and resentment, thereby decreasing employees' commitment level and increasing turnover intention. Third, for employees who continue to pursue a preventionfocused strategy, managers can set higher personal goals and raise team targets above the minimum standard, then coach them to understand loss and non-loss situations for performance deficiencies. As they have concerns about job stability, they will self-regulate to increase their effort behavior and display less social loafing in the work team. Fourth, results of this study suggest that LMX cannot moderate the relationships between promotion focus/prevention focus and social loafing. On the other hand, prevention focus has significant and negative effects on social loafing. Specifically, the stronger hotel employees' prevention focus is, the less their social loafing will be (H2b). This is because cooperating with their team members, working collectively to achieve group goals in a hotel, is their obligation. The more they understand, the more likely it is that an avoidance strategy will be used to prevent a loss situation, thus leading to less social loafing behavior in the team as compared to working alone.

Talent management is highly important nowadays. Employees are human capital and the most important assets in the hospitality industry, especially for five-star hotels attempting to outdo their competition by providing the best customer service. To outsmart competitors, hotels often simply offer on-the-job trainings and train-the-trainer programs to frontline employees. However, training effectiveness may be questionable as there is always an incorrect assumption that training can solve all performance gaps or work problems (e.g., poor performance, customer complaints, high accident rates, etc.). Many training managers, due to time constraints and lack of resources and knowledge, may fail to conduct person analysis. Person analysis is a gap analysis to identify who needs training and a given trainee's readiness for training. This includes an understanding of the trainee's personal characteristics, such as cognitive ability, self-efficacy, attitudes, motivation, and needs (Noe, 2020; Werner \& DeSimone, 2012). The common needs-based motivation theories adopted by human resource development (HRD) professionals do not account for individuals' selfregulation decision-making processes toward their desired end-state. This study, based on Higgins's $(1996,1997)$ regulatory focus theory (RFT), itself extended from motivation theory, sheds light on strategic HRD for learner-centered training design. In most cases, there is no explicit reward or punishment system for employee training. The results of this study explain why 
individuals self-regulate in the decision-making process of training (e.g., promotion-focused employees choosing to devote themselves fully to attending training, as they have a self-drive for personal growth) to a desired end-state (e.g., being aware of the gain situation of improving customer servicing skills that inspire one to exercising higher effort behavior, thereby achieving higher performance ratings and leading to career advancement). On the other hand, preventionfocused employees exercise minimal input and effort in attending the same training due to the absence of loss or non-loss situation, such as the lack of penalty of not attending the training. Such employees may even continue with the undesirable behavior after attending the training. In order to improve training effectiveness for talent development goals, HRD professionals should first identify different employees' orientation toward regulatory foci. They should then design and communicate gain and loss situations in the training program (i.e., "if-then" rules). The findings in this study also suggest the role supervisory support, in the form of LMX, plays in differentiating employees' needs for talent development. To identify promotion-focused or prevention-focused employees for training needs, the measurement scale of regulatory foci is a useful instrument to achieve such purposes.

Finally, the measurement scale can also be applied in the recruitment and selection process. Since promotion-focused employees desire to approach advancement, growth, aspirations, and accomplishments and tend to produce higher-effort behavior, the survey results will help managers to select promotion-oriented individuals to join their companies. In a highly competitive business environment, more promotion-focused employees with a growth mind-set can create an agile work force contributing to positive organizational culture and sustainable competitiveness of organizations.

\section{Limitations and Opportunities for Future Research}

There are several limitations to the current study. During the questionnaire design and data collection process, preventive measures were undertaken to minimize the common method variance (CMV). However, a spurious relationship between variables might still be caused by transverse section design. To avoid such occurrences in future studies, consideration could be made to obtain different variable data at different time points. Moreover, the judgmental sampling method was used, and the sample was comprised exclusively of Chinese hotel employees. It is recommended to be cautious in generalizing the results across different hotel contexts. Future studies should consider widening the geographic scope for more nuanced implications. In terms of providing more substantial managerial implications for the hotel sector to enhance employees' work behavior, future studies can consider investigating the multi-dimensional construct of organizational citizenship behavior. Finally, despite the strength of the quantitative study, in-depth interviews using dyadic studies between supervisors and employees to examine the moderating effect of LMX between regulatory focus and work behavior could also shed light on the study results. 


\section{References}

Akgunduz, Y., \& Eryilmaz, G. (2018). Does turnover intention mediate the effects of job insecurity and co-worker support on social loafing? International Journal of Hospitality Management, $68,41-49$.

Anderson, J. C., \& Gerbing, D. W. (1988). Structural equation modeling in practice: A review and recommended two-step approach. Psychological Bulletin, 103(3), 411-423.

Bagozzi, R. P., \& Yi, Y. J. (1988). On the evaluation of structural equation model. Journal of the Academy of Marketing Science, 16(1), 74-94.

Bernerth, J., Armenakis, A., Feild, H., Giles, W., \& Walker, H. (2007). Leader-member social exchange (LMSX): Development and validation of a scale. Journal of Organizational Behavior, 28(8), 979-1003.

Blau, P. (1964). Exchange and power in social life. New York, NY: Wiley.

Boye, M. W., \& Jones, J. W. (1997). Organizational culture and employee counterproductivity. In R. A. Giacalone \& Greenberg, J. (Eds.), Antisocial behavior in organizations (pp. 172-184). Thousand Oaks, CA: Sage.

Breton, R. (1971). Output norms and productive behavior in noncooperative work groups: A simulation study. Simulation \& Gaming, 2(1), 45-72.

Brockner, J., Grover, S., Reed, T., \& Dewitt, R. (1992). Layoffs, job insecurity, and survivors' work effort: Evidence of an inverted-U relationship. Academy of Management Journal, 35(2), 413-425.

Chang, J. H., \& Teng, C. C. (2017). Intrinsic or extrinsic motivations for hospitality employees' creativity: The moderating role of organization-level regulatory focus. International Journal of Hospitality Management, 60, 133-141.

Chen, S. C., \& Quester, P. G. (2007). Implementation and outcomes of customer value: A dyadic perspective. The Service Industries Journal, 27(6), 779-794.

Dai, Y. D., Dai, Y. Y., Chen, K. Y., \& Wu, H. C. (2013). Transformational vs. transactional leadership: which is better? A study of international tourist hotel employees in Taipei City. International Journal of Contemporary Hospitality Management, 25(5), 760-778. 
Dai, Y. D., Chen, K. Y., \& Zhuang, W. L. (2016). Moderating effect of work-family conflict on the relationship between leader-member exchange and relative deprivation: links to behavioral outcomes. Tourism Management, 54, 369-382.

Dai, Y. D., Hou, Y. H., Wang, C. H., Zhuang, W. L., \& Liu, Y. C. (2018). TMX, social loafing, perceived accountability and OCB. The Service Industries Journal. Doi: $10.1080 / 02642069.2018 .1500554$

Dai, Y. D., Zhuang, W. L., \& Huan, T. C. (2019). Engage or quit? The moderating role of abusive supervision between resilience, intention to leave and work engagement. Tourism Management, 70, 69-77.

Danaher, P. J., \& Mattsson, J. (1994), Customer satisfaction during the service delivery process. European Journal of Marketing, 28(5), 5-16.

Dansereau, F., Graen, G.B., \& Haga, W. (1975). A vertical dyad linkage approach to leadership in formal organizations. Organizational Behavior and Human Performance, 13(1), 46-78.

Daryanto, A., de Ruyter, K., Wetzels, M., \& Patterson, P. G. (2010). Service firms and customer loyalty programs: a regulatory fit perspective of reward preferences in a health club setting. Journal of the Academy of Marketing Science, 38(5), 604-616.

Das, T. K., \& Kumar, R. (2011). Regulatory focus and opportunism in the alliance development process. Journal of Management, 37(3), 682-708.

Dommeyer, C. J., (2007). Using the diary method to deal with social loafers on the group project: Its effects on peer evaluations, group behavior, and attitudes. Journal of Marketing Education, 29(2), 175-188.

Duffy, M. K., \& Shaw, J. D. (2000). The Salieri syndrome: Consequences of envy in groups. Small Group Research, 31(1), 3-23.

Dulebohn, J. H., Bommer, W. H., Liden, R. C., Brouer, R. L., \& Ferris, G. R. (2012). A metaanalysis of antecedent and consequences of leader-member exchange: Integrating the past with an eye toward the future. Journal of Management, 38(6), 1715-1759.

Festinger, L., Pepitone, A., \& Newcomb, T. (1952). Some consequences of de-individuation in a group. The Journal of Abnormal and Social Psychology, 47(2), 382-389.

Fisher, R., McPhail, R., \& Menghetti, G. (2010). Linking employee attitudes and behaviors with business performance: A comparative analysis of hotels in Mexico and China. International Journal of Hospitality Management, 29(3), 397-404. 
Fornell, C., \& Larcker, D. F. (1981), "Evaluating structural equation models with unobservable variables and measurement error", Journal of Marketing Research, Vol. 18 No. 1, pp. 39-50.

George, J. M. (1992). Extrinsic and intrinsic origins of perceived social loafing in organizations. Academy of Management Journal, 35(1), 191-202.

Gorman, C. A., Meriac, J. P., Overstreet, B. L., Apodaca, S., McIntyre, A. L., Park, P., \& Godbey, J. N. (2012). A meta-analysis of the regulatory focus nomological network: Work-related antecedents and consequences. Journal of Vocational Behavior, 80(1), 160-172.

Graen, G.B., \& Cashman, J. (1975). A role-making model of leadership in formal organizations: A developmental approach, In J.G. Hunt \& L.L. Larson (Eds.), Leadership frontiers, (pp. 143-166). Kent, OH: Kent State University Press.

Graen, G.B., \& Uhl-Bien, M. (1995). Relationship-based approach to leadership: development of leader-member exchange (LMX) theory of leadership over 25 years: applying a multi-level multi-domain perspective. Leadership Quarterly, 6(2), 219-247.

Ha, J., \& Jang S. C. (2009). Perceived justice in service recovery and behavioral intentions: The role of relationship quality. International Journal of Hospitality Management, 28(3), 319327.

Hair, T. D., Anderson, R. E., Tatham, R. L., \& Black, W. C. (1998). Multivariate data analysis ( $5^{\text {th }}$ ed.). Upper Saddle River, N.J.: Prentice Hall

Harris, L. C. \& Ogbonna, E. (2002). Exploring service sabotage: The antecedents, types, and consequences of frontline, deviant, antiservice behaviors. Journal of Service Research, 4(3), 163-183.

Hetland, J., Hetland, H., Bakker, A. B., \& Demerouti, E. (2018). Daily transformational leadership and employee job crafting: The role of promotion focus. European Management Journal, 36(6), 746-756.

Higgins, E. T. (1996). The 'self digest'”: self-knowledge serving self-regulatory functions. Journal of Personality and Social Psychology, 71(6), 1062-1083.

Higgins, E. T. (1997). Beyond pleasure and pain. American Psychologist, 52(12), 1280-1300.

Higgins, E. T. (1998). Promotion and prevention: Regulatory focus as a motivational principle. Advances in Experimental Social Psychology, 30, 1-46. 
Higgins, E. T., Friedman, R. S., Harlow, R. E., Idson, L. C., Ayduk, O. N., \& Taylor, A. (2001). Achievement orientations from subjective histories of success: promotion pride versus prevention pride. European Journal of Social Psychology, 31(1), 3-23.

Hung, C. C., Huan, T. C., Lee, C. H., Lin, H. M., \& Zhuang, W. L. (2018). To adjust or not to adjust in host country? Perspective of interactionism. Employee Relations, 40(2), 329-345.

Ilies, R., Nahrgang, J. D., \& Morgeson, F. P. (2007). Leader-member exchange and citizenship behaviors: A meta-analysis. Journal of Applied Psychology, 92(1), 269-277.

Jung, H. S., \& Yoon, H. H. (2015). Understanding regulatory focuses: The role of employees' regulatory focus in stress coping styles, and turnover intent to a five-star hotel. International Journal of Contemporary Hospitality Management, 27(2), 283-307.

Karatepe, O. M., \& Baddar, L. (2006). An empirical study of the selected consequences of frontline employees' work-family conflict and family-work conflict. Tourism Management, 27(5), 1017-1028.

Karatepe, O. M., Beirami, E., Bouzari, M., \& Safavi, H. P. (2014). Does work engagement mediate the effects of challenge stressors on job outcomes? Evidence from the hotel industry. International Journal of Hospitality Management, 36, 14-22.

Karatepe, O. M., \& Kilic, H. (2007). Relationships of supervisor support and conflicts in the workfamily interface with the selected job outcomes of frontline employees. Tourism Management, 28(1), 238-252.

Karatepe, O. M., \& Sokmen, A. (2006). The effects of work role and family role variables on psychological and behavioral outcomes of frontline employees. Tourism Management, 27(2), 255-268.

Karau, S. J., \& Williams, K. D. (1993). Social loafing: A meta-analytic review and theoretical integration. Journal of Personality and Social Psychology, 65(4), 681.

Karau, S. J., \& Williams, K. D. (1997). The effects of group cohesiveness on social loafing and social compensation. Group Dynamics: Theory, Research, and Practice, 1(2), 156-168.

Kim, M., Choi, L., Knutson, B.J., \& Borchgrevink, C.P. (2017). “Hotel employees’ organizational behaviors from cross-national perspectives". International Journal of Contemporary Hospitality Management, 29(12), 3082-3100.

Kuczmarski, S., \& Kuczmarski, T., (1995). Value-Based Leadership: Rebuilding Employee Commitment, Performance, and Productivity. Prentice Hall, Paramus, NJ. 
Latané, B., Williams, K. D., \& Harkins, S. G. (1979a). Social loafing. Psychology Today, 13(5), 104-110.

Latané, B., Williams, K., \& Harkins, S. (1979b). Many hands make light the work: The causes and consequences of social loafing. Journal of Personality and Social Psychology, 37(6), 822.

Lee, C. H., Hung, C. C., Chien, C. S., Zhuang, W. L., \& Hsu, C. Y. Y. (2017). Regulatory Foci and Expatriate Adjustment. Personnel Review, 46(3), 512-525.

Li, Y., \& Sun, J. M. (2015). Traditional Chinese leadership and employee voice behavior: A crosslevel examination. Leadership Quarterly, 26(2), 172-189.

Liden R. C., Wayne S. J., Jaworski R. A., \& Bennett N. (2004). Social loafing: A field investigation. Journal of Management, 30(2), 285-304.

Luo, Z., Qu, H., \& Marnburg, E. (2013). Justice perceptions and drives of hotel employee social loafing behavior. International Journal of Hospitality Management, 33, 456-464.

Markovits, Y., Ullrich, J., van Dick, R., \& Davis, A. J. (2008). Regulatory foci and organizational commitment. Journal of Vocational Behavior, 73(3), 485-489.

Meyer, B., Schermuly, C. C., \& Kauffeld, S. (2016). That's not my place: The interacting effects of faultlines, subgroup size, and social competence on social loafing behavior in work groups. European Journal of Work and Organizational Psychology, 25(1), 31-49.

Mohr, L.A. \& Bitner, M. J. (1995). The role of employee effort in satisfaction with service transactions. Journal of Business Research, 32(3), 239-252.

Mulvey, P. W., \& Klein, H. J. (1998). The impact of perceived loafing and collective efficacy on group goal processes and group performance. Organizational Behavior and Human Decision Processes, 74(1), 62-87.

Murphy, K. R. (1987). Detecting infrequent deception. Journal of Applied Psychology, 72(4), 611614.

Murphy, S. M., Wayne, S. J., Liden, R. C., \& Erdogan B. (2003). Understanding social loafing: The role of justice perceptions and exchange relationships. Human Relations, 58(1), 61-84.

Noe, R. A. (2020). Employee training and development. Eighth Edition. McGraw-Hill.

Podsakoff, P. M., MacKenzie, S. B., \& Podsakoff, N. P. (2012). Sources of method bias in social science research and recommendations on how to control it. Annual Review of Psychology, $63,539-569$. 
Price, K. H., Harrison, D. A., \& Gavin, J. H. (2006). Withholding inputs in team contexts: member composition, interaction processes, evaluation structure, and social loafing. Journal of Applied Psychology, 91(6), 1375-1384.

Rangarajan, D., Jones, E., \& Chin, W. (2005). Impact of sales force automation on technologyrelated stress, effort, and technology usage among salespeople. Industrial Marketing Management, 34(4), 345-354.

Raub, S. (2008). Does bureaucracy kill individual initiative: The impact of structure on organizational citizenship behavior in the hospitality industry. International Journal of Hospitality Management, 27(2), 179-186.

Reynolds, K. E., \& Beatty, S. E. (1999). Customer benefits and company consequences of customer-salesperson relationships in retailing, Journal of Retailing, 75(1), pp.11-32.

Robbins, S. P. (2006). Organizational Behavior. (11th ed.), NJ: Prentice Hall.

Scandura, T., \& Graen, G. B. (1984). Moderating effects of initial leader-member exchange status on the effects of a leadership intervention. Journal of Applied Psychology, 69(3), 428-436.

Slora, K. B. (1991). An empirical approach to determining employee deviance base rates? In Preemployment Honesty Testing: Current Research and Future Directions. Ed. J. Jones. Westport, CT: Quorum Books.

Stark, E. M., Shaw, J. D., \& Duffy M. K. (2007). Preference for group work, winning orientation, and social loafing behavior in groups. Group Organization Management, 32(6), 699-723.

Steiner, I. D. (1972). Group process and productivity. New York: Academic Press.

Stuckey, C. (2016). Preparing leaders for Gen Z. Training Journal, 10, 33-35.

Sujan, H., Weitz, B. A., \& Kumar, N. (1994). Learning orientation, working smart, and effective selling. Journal of Marketing, 58(3), 39-52.

Testa, M. R. (1999). Satisfaction with organizational vision, job satisfaction and service efforts: an empirical investigation. Leadership \& Organization Development Journal, 20(3), 154161.

van Beek, I., Toon, W.T., Schaufeli, W. B., \& Brenninkmeijer, V. (2012). Heavy work investment: Its motivational make-up and outcomes. Journal of Managerial Psychology, 29(1), 46-62.

van Breukelen, W., Schyns, B., \& Le Blanc, P. (2006). Leader-member exchange theory and research: Accomplishments and future challenges. Leadership, 2(3), 295-316.

Wallace, C., \& Chen, G. (2006). A multilevel integration of personality, climate, self-regulation, 
and performance. Personnel Psychology, 59(3), 529-557.

Werner, J. M., \& DeSimone, R. L. (2012). Human resource development. Cengage Learning.

Williams, K., Harkins, S., \& Latané, B. (1981). Identifiability as a deterrent to social loafing: Two cheering experience. Journal of Personality and Social Psychology, 40(2), 303-311.

Yoo, M., Lee, S., \& Bai, B. (2011). Hospitality marketing research from 2000 to 2009: topics, methods, and trends. International Journal of Contemporary Hospitality Management, 23(4), 517-532.

Zhao, X., \& Namasivayam, K. (2012). The relationship of chronic regulatory focus to work-family conflict and job satisfaction. International Journal of Hospitality Management, 31(2), 458467. 